\title{
Why 'small' can be better: an exploration of the relationships between class size and pedagogical practices.
}

\author{
By Gary James Harfitt, The University of Hong Kong \\ (Published in Research Papers in Education)
}

\begin{abstract}
A central issue in the class size debate is that while cutting class size might lead to improved teaching and learning, it is also possible that it may not if teachers do not seek to exploit the advantages of a smaller class size through an alternative pedagogy. Research suggests that teachers do not change their pedagogy when moving from large classes to smaller ones. This paper focuses on pedagogical practices in large and reducedsize secondary school classes where the teacher is the same in both contexts; a research design that has not been employed in previous class size studies. The paper explores the relationships between class size and the pedagogical practices adopted by 4 experienced teachers in Hong Kong who are each responsible for one large and one reduced-size English language class of the same grade level. Drawing on mostly qualitative data, this study's findings show that teachers did vary their teaching from one class to another with important differences noted in teacher-student interaction patterns, classroom organization, the establishment of classroom rules, and the teacher's use of humour. At the same time, interview data reveal that teachers could not always explain or theorise their pedagogical decisions. Implications for professional practice are presented.
\end{abstract}

Key words: small class size; secondary school; teachers' pedagogy; professional development.

\section{Introduction}

Studies of how class size reduction impacts on teaching behaviour have been well documented (Bourke, 1986; Johnston, 1989; Hargreaves, Galton and Pell, 1998). Finn and Achilles (1999) argue strongly that small classes afford powerful teaching opportunities for educators to do more effectively what they know is right in terms of teaching and learning, yet crucially, other research suggests that teachers do not change their practice from a large class to a small one (Shapson, Wright, Eason \& Fitzgerald, 1980; Cahen, Filby, McCutcheon, \& Kyle, 1983; Rice, 1999). A longitudinal study of small class teaching in Primary schools in Hong Kong (Galton and Pell, 2010) reported that following three years of systematic observation, “...only a few significant differences in teaching approach between small and normal size classes” were identified (p.18). Stasz and Stecher (2002) have made a similar claim that there is plentiful research 
pointing to teaching practice being "resistant to change and that teachers adapt their practices slowly and marginally as new materials and techniques are introduced” (p.29). Here, perhaps, is the crux because while cutting class size might lead to improvements in teaching and learning, it is also possible that it may not if teachers do not seek to exploit the advantages of a smaller class size through the adoption of a different pedagogy. But identifying what that alternative pedagogy should be is problematic due to the lack of systematic research on good practices in small class teaching. Galton (1998) and Graue and Rauscher (2009), for example, argue that there are very few clear answers to questions about which strategies teachers should adopt when operating in small classes while Blatchford (2011) suggests that class size research must place emphasis on identifying effective pedagogies in classes of varying size.

One possible reason why there is little information on good practices when teaching small classes is that much of the qualitative data on class size differences has, inevitably, stemmed from teachers' own perceptions of their classrooms. Few studies have actually included systematic observation of teachers, with notable exceptions being Blatchford (2003) and Galton and Pell (2010). Without such kinds of supporting data from classroom observations there may be an over-reliance on teacher reports. This is not aimed at dismissing the teachers' point of view; indeed, it may be concluded that teachers' attitudes towards class size and their practice within a large or reduced-size teaching context could well be a mediating factor in the effectiveness of their pedagogy and the learning outcomes in the classroom. Nevertheless, many of these teacher interviews have taken place outside of the classroom and even with teachers who have not necessarily experienced small class teaching (Pedder, 2006). In Hong Kong, Galton and Pell (2010) observed that questionnaire responses from teachers revealed an almost uniform sense of "professional comfort" (p.12) about the notion of working with small classes, but some of these responses came from teachers who had never previously taught a small class.

This paper, therefore, rests on a standpoint which argues that relying solely on teacher report to examine teaching in reduced-size classes is not enough. With this in mind, this study advocates the observation of teachers working in large and reduced-size classes of 
comparable academic ability, and of the same grade level. It is hoped that findings may help to throw light on what different practices, if any, are adopted by teachers and how effective those practices may be.

\section{The Hong Kong Context}

Hong Kong presently occupies a central position in research on class size because of the Government's decision to roll out a comprehensive small class teaching initiative at Primary school level (from 2009-2010) and more secondary schools adopting small class teaching in key subjects like English, Mathematics and Chinese. This paper originates from an exploratory study that was conducted in the context of an ongoing debate between the teachers' union and the government in Hong Kong on the reduction of large class size in secondary schools (mostly consisting of 40 students or more) and whether reduced class size would lead to better student learning. Pertinent to Hong Kong's current situation of more small class teaching in secondary schools, Blatchford (2011) surmises that if educational institutions are experimenting with class size reduction to improve learning, then it is vital that the teaching is as effective as possible. However, worldwide, there is very limited knowledge or published research on the experiences among secondary school teachers of working with small classes, with the exception of a few studies in the United Kingdom (Pedder, 2001; Blatchford, Basset and Brown, 2011). The benefit of looking at secondary school contexts is that students arguably undertake more complex intellectual tasks here and therefore require more support and scaffolding from their teachers. These support strategies may be more susceptible to class size variation (Pedder, 2006).

One of the most challenging aspects of this issue in Hong Kong is how to define class size. Hong Kong is known for having typically large classes at secondary level, with many having 40 pupils, or more. To put those numbers into perspective, one of the most influential studies on class size conducted in the USA, the Student Teacher Achievement Ratio Project (or STAR Project), included 'regular' class sizes of 22-25 and 'small' class

sizes of 13-17 in its examination of class size on student achievement in Tennessee, USA (see Finn and Achilles, 1999). Arguably, such small class sizes are unfeasible in Hong 
Kong and make generalisability very difficult in the local context. The study reported in this paper therefore adopted different criteria for defining small and large class size. In 2008, the Hong Kong SAR Government announced plans to reduce class sizes from 40 to 36 at grade 7 level, so the figure of 37 or above was seen as constitutive of a 'large' class for the purposes of this study. As mentioned, authorities in Hong Kong have initiated small class teaching in Primary schools with a maximum student cohort of between 25 and 30 , so in this study a middle figure of 27 or below was proposed as a definition of a small or reduced-size class. Table 1 presents the class sizes that made up the data set for the study.

Table 1 Secondary school class sizes in this study and teacher identifier

\begin{tabular}{|lccc|}
\hline Form level (grade) & Small class size & Large class size & Teacher ID \\
\hline S.3 (grade 9) & $\mathrm{n}=25$ & $\mathrm{n}=41$ & $\mathrm{~T} 1$ \\
\hline S.2 (grade 8) & $\mathrm{n}=25$ & $\mathrm{n}=40$ & $\mathrm{~T} 2$ \\
\hline S.2 (grade 8) & $\mathrm{n}=21$ & $\mathrm{n}=39$ & $\mathrm{~T} 3$ \\
\hline S.4 (grade 10) & $\mathrm{n}=27$ & $\mathrm{n}=37$ & $\mathrm{~T} 4$ \\
\hline
\end{tabular}

\section{Literature Review}

It is said that more has been written on the effects of class size on academic achievement than on any other issue in education (Goldstein and Blatchford, 1998), yet very little research has been conducted on gathering evidence of effective teaching practices in small classes. There has been a tentative model of teaching suggested in small classes based on three aspects: better knowledge of students, more instructional time and teacher satisfaction and therefore the use of a more individualized pedagogy in the classroom (Molnar et al., 1999; Anderson, 2000; Wang and Finn, 2000). As seen from previous research on the possible advantages of class size reduction, smaller classes may well give teachers more time to attend to students' individual learning and social needs which may, in turn, promote greater use of collaborative work such as group and pair work, the benefits of which have been well documented (Blatchford, Kutnick, Baines and Galton, 2003). However, a problematic aspect for researchers in this area is the absence of a clear definition of what effective teaching in smaller classes might look like. 
This lack of knowledge makes giving practical advice to educators on how best to teach small classes difficult. Another reason for the lack of knowledge on effective pedagogy in smaller contexts is that much of the focus of class size research has been on academic achievement or measurable learning outcomes rather than the types of pedagogy being practiced in those classes. For example, the aforementioned STAR Report largely employed quantitative methods in its longitudinal examination of the effects of class size on academic achievement. This included a drawback in that it failed to compare the behaviour of more effective reduced class size teachers with that of less effective reduced class size teachers (Wilson, 2002). In fairness, this is not easy to achieve because of the variables involved in studying different teachers working in separate contexts. Teacher factors such as age, gender, experience, attitude, decision making at the interactive level, pedagogical strategies all interact and have an impact on the quality of teaching and learning making it harder for researchers to offer valid and accurate explanations of how and why class size can make a difference to teaching and learning.

Other views on what type of teaching strategies are required in small classes have been put forward with Graue and Rauscher (2009) stating that effective teaching in small class contexts requires specific actions by teachers to properly exploit the learning opportunities available. According to other research, however, such actions may not be necessary because the reduction in student numbers will automatically lead to benefits for students and teachers (Achilles, 1999) In sum, this argument means that no special form of training is needed for teachers in small classes and that teaching will take care of itself because of the inherent benefits of reduced class size. This further complicates the issue for if we accept that teachers do not change their pedagogy when moving from large to small classes (Shapson et al, 1980), it seems logical that more support is needed in professional development both in schools and at the teacher training level.

Having established that the literature on class size does not really provide educators with a specific set of effective teaching strategies to adopt in small classes, there is the claim that "the principles of effective teaching are the same in classes of all sizes" (Galton \& Pell, 2010 p.6-7). In an extensive review of the literature on effective teaching of a 
general nature (e.g. Brophy \& Good, 1986), Galton and Pell highlighted six pedagogic principles which they believed would facilitate students' understanding: a clear statement of learning objectives to students at the start of a lesson, the use of extended questioning techniques, increasing pupil participation, using group and pair work to promote a spirit of cooperation among learners, providing feedback that promotes student reflection and self correction and, finally, the adoption of an assessment for learning framework. These six principles guided the small class study and professional development programmes that foreshadowed the implementation of a massive small class policy initiative in Hong Kong Primary schools in 2009.

Research also points to the importance of 'dialogic teaching' a concept elaborated by Alexander (2004) which is applicable to classes of all size. This form of teaching promotes more discussion among students in class above the use of instructional talk, the use of more open questions, not closing interactional opportunities down and allowing students longer wait-time when processing questions. Such a pedagogical approach is at odds with Confucian-heritage cultures (CHCs) like Hong Kong which have been characterized by whole class teaching (Biggs, 1998) and where teachers are stereotypically viewed as authority figures (Littlewood, 1999).

This study, then, sets out to examine the relationships between class size and pedagogical practice by focusing on teachers working in large and small classes of the same grade level. A goal of this paper is to identify pedagogical practices which may contribute to a better understanding of what effective teaching in small or reduced-size classes might look like. Findings may have implications for pedagogical practice in small and large classes.

\section{Methodology}

This paper draws on interviews and lesson observations carried out as part of multiple case studies which focused on teachers working in different Hong Kong secondary schools, but who were all responsible for teaching one large class and one reduced-size class at the same grade level in their respective schools. In each case study, then, both 
classes were taught by the same teacher, which to my knowledge represents an original research design in the study of class size and one that differs from previous studies of class size reduction where the teacher variable was not controlled in case study research (Blatchford, 2003; Galton and Pell, 2010).

A multiple case study approach aimed at outlining, enhancing and expanding theories and concepts around the issue of class size. A 'case' in this study constitutes the same teacher teaching a large class as well as a smaller class of comparable level and academic ability. Adoption of a multiple case study is to determine if findings can be found across more than one case and this replication strategy (Yin, 1991) then helps to strengthen our understanding of individual cases. Although this study adopted a naturalistic approach, some attention was paid to exerting control over key variables that would have an impact on classroom interaction and learning, namely, the teacher, the content of the lesson (including the topic and the language skills) and the academic ability of the students. Research in the case study schools was conducted over a two-year period.

\section{Participants}

Access to the schools and lessons for the purposes of observation and video recording was guided by the research design, and I was able to identify cases which fit into the research design of this study through extensive contact with the local school community. All the schools came from the same urban area of Hong Kong, Kowloon, and all schools were co-educational. Four English teachers volunteered to have their lessons observed and video-recorded over one cycle of teaching (approximately 8 lessons in each cycle with each lesson lasting for 40mins). The selection of participating teachers was limited by their own willingness to be observed as well as the permission of their schools and all of these observed classes formed part of the teacher's existing teaching schedule. In other words, the class sizes and the teaching arrangements had all been initiated by the individual schools with no intervention on my part, as researcher. The four teachers were all female and all held Master's degrees in Education and had between 5 and 20 years experience and can therefore be described as experienced educators (Tsui, 2003). Each 
teacher participated on the condition that they would remain anonymous in this study and so each teacher participant has been given a label: T1-T4.

\section{Data Collection Procedures}

The database for the study includes a total of 29 semi-structured interviews with the teachers across the four case study schools as well as 60 lesson observations. To recapitulate, the research design required that one teacher was responsible for teaching two English language classes of the same grade level, one of which was a large class (more than 37 students) and one of which was a reduced-size class (containing 27 students or fewer). The two classes in each case study school needed to be of comparable ability and to ensure this I was able to examine the mid-year examination results for the classes in each school.

\section{Semi-structured interviews}

Interviews allow researchers to gain access to participants' minds (Tuckman, 1972) and a baseline interview was held with each teacher before the observation period commenced. This allowed me to obtain teacher's personal viewpoints and experiences of teaching their respective classes, one large and one smaller class. More regular interviews with the teacher participants were carried out during the classroom observation periods, normally after each class or as soon as the teacher was available to talk. Interviews mostly focused on the following issues: lesson aims and objectives, reference to particular classroom episodes and incidents, discussion of the teachers' pedagogical decisions, the teachers' organization of classroom learning, the teachers' views on classroom interaction in the two classes, the teachers' views on students' relationship with one another, how teachers viewed the characters of their students in the respective classes, and teachers' views on opportunities for individualized teaching in their classes. Interviews typically ranged from 20 minutes to 50 minutes with each being audio-recorded and subsequently transcribed.

\section{Classroom Observations}


Classroom observations allowed for data to be generated on classroom events and discourse in the large and reduced-size classes taught by each teacher. Interviews with teachers may be insufficient on their own without triangulation with observational data to ensure greater trustworthiness (Bassey, 1999) and observations placed emphasis on each teacher's attempts to enhance the learning environment and the students' behaviour within that environment. For instance, each time a teacher varied her classroom layout from the norm during lessons (i.e., from the original student seating plan) I recorded it in my field notes because by organizing their classroom and rearranging existing classroom seating plans in order to vary classroom dynamics (incorporating pair work, group work, reading circles etc.) it might be seen that a teacher is actively engineering the opportunities for increased student-student interaction. Developing a sharper awareness of the dynamics of classroom communication and how it might shape students' participation in language learning activities has been seen as a vital element in promoting the effectiveness of teachers in language classrooms (Walsh, 2006) and so field notes were also used to record question types and interaction patterns between students and teachers.

All observed lessons were transcribed with salient episodes being extracted for analysis both quantitatively and qualitatively. For example, the numbers of times a teacher employed open questions or referred to a student by name during lessons were noted and quantified. This allowed for a comparison to be made of the teacher's discourse in her large and small class over one teaching cycle. I also broke lesson transcriptions into smaller classroom episodes and employed a three-part exchange structure, namely initiation, response and follow-up move or I-R-F (Sinclair \& Coulthard, 1975) to analyse classroom discourse in each of the classes (see sequence 1-4). This reference to I-R-F is included in response to the reviewer's comment about more detail needed to explain my illustrative extracts in the findings section. I have also made a brief recap just before introducing the first sequence on p.12.

I transcribed all interviews with data analysis following a grounded theory approach. Interview transcripts, daily field notes and salient themes underwent an iterative process 
of data reduction and verification (Miles and Huberman, 1994). Interview data were analysed using three stages of coding: open, axial and selective coding (Strauss and Corbin, 1998) and all interview data were compared so that patterns could be identified.

Trustworthiness in conducting this qualitative study was ensured by prolonged engagement with each case combined with a persistent observation of the salient features in each case (Lincoln and Guba, 1985). Member checking is advocated when collecting data in qualitative studies (see Stake, 1995) and respondent validity was achieved by teachers reading and approving all interview and lesson transcriptions. All observations were conducted without any form of participation on the part of the researcher and no feedback on the teachers' work in each class was given until after the cycle of teaching was complete.

\section{Findings}

This section describes teachers' perceptions and pedagogical practices in small classes by drawing on illustrative examples from semi-structured interviews as well as classroom observation data. This selective use of data is necessary to adhere to the space limitations of an article like this while still exemplifying salient findings from the research as a whole. The extracts presented here are deemed to be representative of the wider data bank which was generated by the study. I will report on three key themes that emerged from the case studies and these include different interaction patterns in the smaller classes, teachers' knowledge of students in smaller classes and the mismatch between teachers' beliefs and practices.

\section{Different interaction patterns in small classes}

During interviews, teachers claimed that they did not change their pedagogy between large and small classes, but observational data from field notes and lesson transcriptions suggests otherwise. To recapitulate, illustrative extracts are taken from full lesson transcripts and then broken into exchanges using Sinclair and Coulthard's (1975) InitiateRespond-Feedback sequence (IRF). In the first selected example, T1 is working with her students $(n=25)$ on the topic of the food pyramid and healthy eating and is collecting 
worksheets from her class (the first few groups to submit win a prize in sequence 1) before checking answers with them. The following sequences from T1's large and reduced-size class reveal some important differences between the classroom interaction and the pedagogy across both classes:

Sequence 1: Extract from small class teaching of T1

\begin{tabular}{|c|c|c|c|c|}
\hline Ex 1 & 1 & I & S2: & Missie [handing in worksheet] \\
\hline & 2 & $\mathrm{R}$ & T: & $\begin{array}{l}\text { Yes, I'm coming my darling [students laugh] } 5 \text { already! } \\
\text { [meaning } 5 \text { groups have handed in their worksheet] }\end{array}$ \\
\hline \multirow[t]{2}{*}{ Ex 2} & 3 & I & & Pens down now. Jonathan, I'm sorry. \\
\hline & 4 & $\mathrm{R}$ & $\mathrm{J}:$ & [student puts pen down] \\
\hline \multirow[t]{3}{*}{$\begin{array}{l}\text { Ex } 3 \\
\text { Ex } 4\end{array}$} & 5 & I & T: & $\begin{array}{l}\text { Let's check the answers together. } \\
\text { [Teacher gives out some sweets to the winners]. } \\
\text { Who else won? }\end{array}$ \\
\hline & 7 & $\mathrm{R}$ & S3: & Here! We won. \\
\hline & 8 & F & T: & Not you... you did not win [students and teacher laughs] \\
\hline \multirow[t]{3}{*}{ Ex 5} & 9 & I & & So shout out the answers. Name of the food at the top. \\
\hline & 10 & $\mathrm{R}$ & Ss: & Chocolate, soya sauce. \\
\hline & 11 & F & T: & Chocolate, soya sauce. Yes. \\
\hline \multirow[t]{2}{*}{ Ex 6} & 12 & I & $\mathrm{T}:$ & Why do we need that food? \\
\hline & 13 & $\mathrm{R}$ & Ss: & Tastes good. \\
\hline \multirow[t]{2}{*}{ Ex 7} & 14 & I & T: & What about the next (one)? \\
\hline & 15 & $\mathrm{R}$ & Ss: & Fish tuna...tuna fish...meat \\
\hline \multirow[t]{2}{*}{ Ex 8} & 16 & I & $\mathrm{T}:$ & Why do we need meat? Yes Stefanie? \\
\hline & 17 & $\mathrm{R}$ & St: & To grow cells. \\
\hline \multirow[t]{3}{*}{ Ex 9} & 18 & $\mathrm{I}$ & T: & Next one? What else? What else? Ben? \\
\hline & 19 & $\mathrm{R}$ & S4: & Milkshake and ice-cream. \\
\hline & $\begin{array}{l}20 \\
21\end{array}$ & $\begin{array}{l}\text { F1 } \\
\text { F2 }\end{array}$ & $\mathrm{T}:$ & $\begin{array}{l}\text { Thanks Ben. } \\
\text { Karen also has beancurd here. Good. }\end{array}$ \\
\hline \multirow[t]{2}{*}{ Ex 10} & 22 & I & $\mathrm{T}:$ & One more? Does anyone have another answer? \\
\hline & 23 & $\mathrm{R}$ & S: & Vegetables \\
\hline \multirow[t]{3}{*}{ Ex 11} & 24 & $\begin{array}{l}\text { F1 } \\
\text { I }\end{array}$ & $\mathrm{T}:$ & $\begin{array}{l}\text { That's right. Vegetables. Give me the names of two. Can you } \\
\text { give me the names of two vegetables? }\end{array}$ \\
\hline & 25 & $\mathrm{R}$ & Ss & Carrot...mushroom...beans...pumpkin... \\
\hline & 26 & $\mathrm{~F}$ & T: & More than two. Excellent. \\
\hline
\end{tabular}

Sequence 1 portrays a relaxed and personalized atmosphere evidenced by the number of exchanges between students and $\mathrm{T} 1$ and the frequent use of students' names by the teacher. It is also noteworthy how many responses the teacher is able to elicit from her students (see exchanges 4-11). In line 9, T1 demonstrates that she does not want the students to put up their hands when shouting out answers (which is not the usual practice 
in Hong Kong classrooms). There are also jokes between the teacher and students as seen in line 7 where one student tries to claim a prize, even though his group did not hand in their work on time. The close relationship between teacher and students is highlighted in the way T1 addresses her students by their names, even referring to one of them as "my darling” (see line 2). In sequence 2, T1 is covering the same material with her large class $(n=41)$ in a lesson shortly after the one described in sequence 1 . An immediate difference in pedagogy is that the teacher does not set up a competitive task whereby students have to submit their work in return for prizes, or sweets.

Sequence 2: Extract from large class teaching of T1

\begin{tabular}{|c|c|c|c|c|}
\hline \multirow[t]{2}{*}{ Ex 1} & 1 & I & $\mathrm{T}:$ & $\begin{array}{l}\text { Right let's see what recipes you have. Do you have them with } \\
\text { you? }\end{array}$ \\
\hline & 2 & & Ss: & [no response from students] \\
\hline \multirow[t]{2}{*}{ Ex 2} & 3 & Re-I & T: & Do you have them? Yes or no? \\
\hline & 4 & $\mathrm{R}$ & Ss: & Yes. \\
\hline \multirow[t]{2}{*}{ Ex 3} & 5 & I & $\mathrm{T}:$ & $\begin{array}{l}\text { Right, so take them out and put them on your table. On the } \\
\text { table in front of you. OK. }\end{array}$ \\
\hline & 6 & $\mathrm{R}$ & Ss: & [students comply with the teacher's instruction] \\
\hline \multirow[t]{2}{*}{ Ex 4} & 7 & $\mathrm{I}$ & $\mathrm{T}:$ & So what have we got? Can anyone start? \\
\hline & 8 & & S: & [no response from students] \\
\hline \multirow[t]{2}{*}{ Ex 5} & 9 & Re-I & T: & Who would like to start? \\
\hline & 10 & & Ss: & [no student volunteered to start] \\
\hline \multirow[t]{2}{*}{ Ex 6} & $\begin{array}{l}11 \\
12\end{array}$ & Re-I & T: & $\begin{array}{l}\text { What's this one? (picking up one example from front desk?) } \\
\text { What's this one? Can you see? }\end{array}$ \\
\hline & 13 & $\mathrm{R}$ & Ss: & Rice ... fish \\
\hline \multirow[t]{2}{*}{ Ex 7} & $\begin{array}{l}14 \\
15\end{array}$ & $\begin{array}{l}\mathrm{F} \\
\mathrm{I}\end{array}$ & $\mathrm{T}:$ & $\begin{array}{l}\text { Yes there is rice and fish and lots of shell fish as well. } \\
\text { Does anyone know what this is? }\end{array}$ \\
\hline & 16 & & Ss: & [no response] \\
\hline \multirow[t]{2}{*}{ Ex 8} & 17 & Re-I & T: & What is it? \\
\hline & 18 & & Ss: & (no response) \\
\hline \multirow[t]{3}{*}{ Ex 9} & $\begin{array}{l}19 \\
20\end{array}$ & $\begin{array}{l}\mathrm{R} \\
\mathrm{I}\end{array}$ & T: & $\begin{array}{l}\text { Its paella } \ldots \text { paella. } \\
\text { Can you say after me? }\end{array}$ \\
\hline & 21 & $\mathrm{R}$ & Ss: & PAELLA \\
\hline & 22 & $\mathrm{~F}$ & T: & That's right. \\
\hline \multirow[t]{2}{*}{ Ex 10} & 23 & $\mathrm{I}$ & T: & Does anyone know which country is famous for paella? \\
\hline & 24 & $\mathrm{~F}$ & T: & You probably don't know. It’s Spain. Spain. \\
\hline
\end{tabular}

This sequence differs greatly from the one in the small class. Firstly, T1's questions are aimed at the whole class. It is also noted that the teacher fails to elicit a response from 
students in several exchanges (see exchanges 1, 4, 5, 7, 8 and 10) and at times T1 answers her own question when the students fail to provide an answer (line 19). T1 reinitiates her questions on several occasions to elicit responses and when students do answer her (see lines 4, 13 and 19) their contributions are minimal. Another contrast with the small class is there is not a single instance where T1 addressed her students individually by name. Unlike sequence 1 , no sweets are offered to try and encourage students' participation. I have made a few small additions here to clarify and elaborate on some of the findings shown in the sequences (1-4).

In interview, T1 acknowledged that she "had more fun" in the small class and that she had been able "to build a close relationship with the students" but the difference in the way she interacted with the large class is shown in this interview extract,

It's true I don't really know all of them... I don't have time. With the large class I put more burden on myself and lessons are more teacher centred. I provide them with everything which means they are relatively used to learning passively. I kind of mould their learning habits...I can control the class and the lecture style is easiest.

T1, here, appears to be saying that the teacher-centred discourse observed in sequence 2 was a deliberate strategy employed to keep the class under control because of its large size. This was a typical finding across most of the case studies with more open questions, more use of students' names and more humour from teachers and students all being observed and recorded in the small classes.

A similar illustration was found in observations of T3's classes. In both classes students were asked to read a newspaper article and then give an oral presentation on the content. Feedback on students' use of grammar, organization, speed and content was then given by other students and the teacher. Again, the two sequences from the large and small classes $(n=39$ and $n=21)$ reveal differences in classroom interaction and in the teacher's pedagogy:

Sequence 3: Extract from small class teaching of T3

\begin{tabular}{|l|l|l|l|l|}
\hline Ex 1 & 1 & I & T: & I think you are ready. You can present from your own seats if \\
\hline
\end{tabular}




\begin{tabular}{|c|c|c|c|c|}
\hline & & & & that is easier for you. But you must speak clearly. Are you ready \\
\hline & 2 & $\mathrm{R}$ & Ss: & No [students laugh] \\
\hline & 3 & F & T: & $\begin{array}{l}\text { Very funny. I can see you are ready. Ann you have been ready } \\
\text { for a while because I was watching you finish your notes... }\end{array}$ \\
\hline & 4 & $\mathrm{R}$ & S1: & Not ready. Not ready. Not yet \\
\hline Ex 2 & $\begin{array}{l}5 \\
6 \\
7\end{array}$ & $\begin{array}{l}\mathrm{F} \\
\mathrm{I} \\
\mathrm{R}\end{array}$ & $\begin{array}{l}\text { T: } \\
\text { T: } \\
\text { S2 }\end{array}$ & $\begin{array}{l}\text { OK I'll come back to you but you will be next Ann. } \\
\text { Would anyone like to start? } \\
\text { [student raises his hand to volunteer] }\end{array}$ \\
\hline Ex 3 & 8 & F & T: & $\begin{array}{l}\text { Excellent. Thank you Tim. Do you want to stay there [points to } \\
\text { student's seat] or come to the front? }\end{array}$ \\
\hline & 9 & $\mathrm{R}$ & S2: & I'll stay here. \\
\hline Ex 4 & 10 & $\begin{array}{l}\text { R- } \\
\text { I }\end{array}$ & T: & $\begin{array}{l}\text { Good. I want the rest of you to think of a question for Tim after } \\
\text { he finishes or you can give him advice. What sort of things can } \\
\text { you ask him? }\end{array}$ \\
\hline & 11 & $\mathrm{R}$ & S3: & Give comments...constructive advice \\
\hline & 12 & $\mathrm{R}$ & S4: & Ask about his content... \\
\hline & 13 & $\mathrm{R}$ & S5: & Tell him to explain more \\
\hline & 14 & $\mathrm{R}$ & S6: & Give advice \\
\hline & 15 & $\mathrm{~F}$ & $\mathrm{~T}:$ & $\begin{array}{l}\text { Good. You all remember what we need to do. OK Tim over to } \\
\text { Make sure we can hear you. Good luck. }\end{array}$ \\
\hline
\end{tabular}

In this sequence, $\mathrm{T} 3$ gives her students the choice of presenting from the front of the class or from their own seats. In interview afterwards, T3 explained that this was to reduce students' anxiety about speaking in front of their peers. This awareness of her students' feelings about language learning is also evident in lines 3-5 where she gives Ann a little more time after hearing that the student was not ready "yet". However, T3 makes the point to the pupil that she will ask her to present next thereby ensuring the students' participation. In line 7 one student volunteers to start the presentation but this is not always a typical response. Towards the end of the sequence (lines 11-15) the students are asked to recall the types of feedback that they must give to their classmate and several students volunteer answers. In sequence 4, T3 is setting up the same task with her large class students.

Sequence 4: Extract from large class teaching of T3

\begin{tabular}{|l|l|l|l|l|}
\hline Ex 1 & 1 & I & T: & $\begin{array}{l}\text { We are going to start the presentations now. Does anyone } \\
\text { want to volunteer? }\end{array}$ \\
\hline & 2 & & Ss: & [no response from students] \\
\hline Ex 2 & 3 & Re-I & T: & $\begin{array}{l}\text { I guess not. OK I'll call out your class number and if you are } \\
\text { lucky enough to be called I want you to come out here [points }\end{array}$ \\
\hline
\end{tabular}




\begin{tabular}{|l|l|l|l|l|}
\hline & & & & to the front of the class]. Is that clear? \\
\hline & 4 & R & Ss: & Yes. \\
\hline Ex 3 & 5 & I & T: & $\begin{array}{l}\text { The first number I will call is number 22. Where are you? } \\
\text { Luke that's you isn't it? Stand up please. Ready? }\end{array}$ \\
\hline & 6 & R & S: & [Luke stands up] \\
\hline Ex 4 & 7 & I & T: & So speak clearly please. I want to hear you. Are you ready? \\
\hline & 8 & & S: & [Luke nods head] \\
\hline Ex 5 & 9 & Re-I & T: & $\begin{array}{l}\text { OK start. Start now. You have 2 minutes [sets timer on } \\
\text { blackboard] }\end{array}$ \\
\hline & 10 & I & S1: & Student makes his presentation \\
\hline
\end{tabular}

In sequence 4 the students also make their verbal presentations, but there are some differences with the corresponding extract from the small class. In this class, no students volunteer to start and T3 makes little effort to interact with individual pupils as she had in the smaller class. This results in T3 nominating a pupil to start by using their class numbers for random selection. The students are asked to present from the front and are not given the choice of presenting from their own seat in the class. Another pedagogical difference is that the class is not asked to provide feedback to the speaker in this lesson with Luke being told in rather summative fashion that he has 2 minutes to complete his presentation. Notably, these pedagogical choices from the teacher result in minimal student participation, until Luke commences his speech which contrasts with the more extensive contribution of students in sequence 3.

Classroom observations also revealed other pedagogical differences, particularly in the way teachers organized their classroom layouts. Field notes were used to record the number of times teachers varied the organization of learning in their large and small classes during lessons and it was found that group work and pair work were organized more frequently in the small classes than in the large classes over the cycle of teaching observed. T1 changed her classroom layout once in the large class compared with eight times in her smaller class. T2 changed her small class layout four times compared with once in her larger class. T4 reorganized the layout in her small class seven times compared to two in the large class. T3 was the exception making just one change to the classroom organization in both classes over the observation period. This section has been moved up as it relates better to pedagogical differences in the observed classes. 


\section{The mismatch between teachers' beliefs and practices}

This section has been moved up as it then shows the contrast between the pedagogical differences and the teachers' inability to explain or theorise their practices, showing the gap that needs to be addressed in schools.

Thus far, observational data reveal that teachers do vary their pedagogy from large to small classes but, intriguingly, interview data suggest that teachers are unable to articulate that they do consciously change their practice which echoes research on teaching small classes cited earlier. For example, when prompted about the pedagogical differences in her two classes, T3 admitted,

I do the same things with both classes. I have not got the time to make up new things for one class so they both get the same. It's easier that way. (T3)

Similarly, when asked to describe specific changes to the teaching of her smaller class, T1 acknowledged that there were "none, really" but that the change was mostly “psychological”,

...it's hard to have 40 students because of all the marking and deadlines for homework. I felt relieved to be honest. (T1)

T1 noted that she taught both classes "in much the same way because it's easier" and although T4 described herself as taking on a different role in the small class ("I am able to facilitate more and joke more in the small class"), she acknowledged, too, that "things are very similar between the classes as I don't have time to change my approach that much.” What was interesting, however, was that these teachers appeared to recognize the opportunities that a small class afforded them. T3, for example, stressed that teaching a small class granted her more "freedom", particularly in the way she planned and implemented instructions and tasks in lessons and described the small class as a "perfect environment”,

In the small class I am able to try out all the approaches I learned on my teacher training courses: pair work, group work and things like that... (T3) 
Teachers were unanimous in describing their small classes as being better in terms of management with T2 admitting that she, "no longer has to take a deep breath before entering the class. It's much more pleasant now...”, citing poor management in previous large classes that she taught.

\section{“Knowing" students better in small classes}

T1's interaction with her small class (see sequence 1) was quite representative of all the cases. In interview the teachers said that smaller classes had allowed teachers to know their students better and this was reflected in the more frequent use of names of the small class students in the classroom episodes presented earlier. This point about "knowing" students better in small classes was made by $\mathrm{T} 4$,

I know this class better [small class]. I got to know them much faster than the large class. In one month of teaching I know them, but the larger classes take much more time. (T3)

However, knowledge of students did not only manifest itself in teachers' use of names in class. T1 noted that a small class allowed her "to build a class spirit where we are all working together" and that this was made possible because of a strong mutual understanding between them. In interview teachers were better able to describe individual students in the small classes and, crucially, were able to describe the learning strategies and personalities of those students. This illustration comes from T2,

I think Cindy is trying really hard now. You know she struggled with her oral English because she is so nervous about speaking but I have been able to help her by asking her to record readings and by putting her with other students in the class who I know will support her in speaking activities. I keep encouraging her and I think she is much more daring now. (T2)

This knowledge of Cindy's learning style and her previous weaknesses in speaking enabled T2 to provide beneficial feedback and support which appears to be ongoing. No such examples from the large classes were offered by teachers.

\section{Implications and conclusions}


The small sample size notwithstanding, findings from the teachers seem to point to several observable good teaching practices in smaller classes. I have added more references to the limitation of this study. The reviewer rightly noted that with only 4 teachers it is hard to generalize and I have tried to address this. These practices also appear to echo some of the characteristics of dialogic teaching namely listening to each other, mutual support, cumulative and collective learning (Alexander, 2004). Previously cited research has suggested that while teachers may perceive psychological and practical benefits to class size reduction, it does not always translate into an alternative pedagogy. It is a longstanding belief that teachers assigned to smaller classes do not significantly alter the instructional methods they use in larger classes (Galton and Patrick, 1990) which, in turn, appears to echo an oft-cited view on the conservative nature of teachers in general (Lortie, 1975). Contrary to that research and my own expectations at the start of this study, teachers observed in this study did adopt different approaches in their small classes compared with their larger classes: more group work and pair work, different interaction patterns, greater use of open questions, more individualization, lengthier wait-times, different classroom rules and more humour. Sustained periods of teacher interaction with individual pupils involving, in particular, challenging questioning and feedback might be seen as crucial determinants of pupil progress and all were identified more in the small classes in this study. In interview, teacher participants talked about a positive classroom atmosphere where students and teachers are closer, where teachers can provide more frequent and more effective types of feedback and where students are willing to speak up more than their counterparts in the large classes.

A significant question has emerged from this study which concerns possible responses for teachers, school managers and teacher educators. In interviews prior to, and during the observational periods, the teachers maintained that they did not change their practice and were largely unable to explain or theorise their decisions when they did, a point suggested in the Hong Kong small class study of Primary schools (Galton and Pell, 2010). For example, when asked what they liked most about teaching small classes, all the respondents cited "better classroom management" as their first answer. Some teachers openly spoke about the opportunities the small classes gave them to experiment and T3 
claimed that she could use group and pair work more regularly. However, in observation she adopted whole class teaching and varied the classroom layout just once in eight observed lessons in the small class. This meant that some students were sitting all alone in single seats away from their peers, thereby denying them access to intellectual resources. It may be, then, that when teachers do change their practice as in this study they are not always able to explain the pedagogical principles behind their choices or to undertake a systematic change in all their lessons. But, whether teachers are able to articulate explicitly the differences between large and small class teaching is possibly not as important as enabling teachers to see what opportunities there are when the class size is reduced, and how they should capitalize on these opportunities when in the classroom.

It may be that the smallness of the class automatically provides opportunities to teachers; in this study some teachers exploited those opportunities more than others but it would be erroneous, perhaps, to subscribe to Achilles' (1999) view that cutting class size is sufficient on its own as a way of mediating change. If, as this study suggests, more examples of dialogic teaching can be found in small classes and might be better promoted in these classes, it would surely be helpful to disseminate and maximize those examples. This might then make such examples a more systematic part of a teacher's pedagogical approach in classes of all size, but in particular the types of small classes described here. This is why teacher educators and to a large extent, school managers are so important in identifying and promoting good practices.

Starting at the school level school managers might assist in promoting a wide range of collaborative activities which would mediate discussion and learning among teachers. Johnson (2009) proposes several inquiry-based professional development models including the establishment of critical friends groups, peer coaching, lesson studies, teacher study groups and cooperative development initiatives. These models, she concludes, would enable professional development to be identified as "learning systematically in, from, and for practice. They recognize that participation and context are essential to teacher learning” (Johnson, 2009, p.112). These proposals also require teachers having time and space to engage with reflective practices, something which in 
this study, teachers said they lacked. Although this study focuses on Hong Kong, the issue of long working hours for teachers is surely a global issue and raises important questions for educators at all levels because in order to promote successful small class teaching, management must surely take a leading role in providing teachers with the physical and mental room for changing their practice. In each teaching context featured in this study, the four teachers were unable to cite any support systems in place in their school for colleagues to share and disseminate good practices on small class teaching. In the absence of this kind of professional development and support, it may not be possible for teachers to examine their own classroom lives in order to promote professional learning and maximize the benefits of small class teaching.

At tertiary level more focus might be placed on promoting better knowledge among student teachers of key aspects of dialogic teaching raised by Alexander (2004) as crucial components of an effective pedagogy in small classes, as well as large ones. Using classroom communication as an example, the opportunities for interaction that may arise naturally in an ELT setting can only be exploited if the teacher is aware of those opportunities and is willing to take advantage of them (Ellis, 1998), something which was not always evident during classroom observations reported upon in this paper. Teacher trainers, accordingly, may exemplify this through microteaching, school visits and dissemination of similar case studies to help teachers articulate and then exploit the benefits of class size reduction through the development of a battery of teaching strategies.

This study has its limitations and a larger cohort of teachers would clearly benefit this type of research. Again I have tried to address the issue of sample size here as a limitation. Because of time constraints it was also unable to examine if and how the good practices identified in this paper lead to academic achievement in students. For that to happen, longitudinal studies must be undertaken examining multiple teachers working in large and small classes over a longer period. Nevertheless, by adopting a research design which provided an emic perspective of teaching and learning in large and small classes, this paper adds to our understanding and awareness of teaching in small classes. 
Author: $\quad$ Dr Gary James Harfitt

Email: gharfitt@hku.hk

Corresponding address: Room 123, Hui Oi Chow Building, Faculty of Education, Hong Kong University, Hong Kong.

\section{REFERENCES}

Achilles, C. M. (1999). Let's put kids first, finally - getting class size right. California: Corwin Press, Inc.

Alexander, R. (2004). Towards Dialogic Teaching: Rethinking Classroom Talk. York: Dialogos.

Anderson, L. W. (2000). Why should reduced class size lead to increased achievement? In M. C. Wang \&. J. D. Finn (Ed.), How Small Classes Help Teachers do Their Best (pp. 3-24). Philadelphia, PA: Temple University Center for Research in Human Development and Education. .

Bassey, M. (1999). Case Study Research in Educational Settings Open University Press, Buckingham Philadelphia.

Biggs, J. (1996). Western misperceptions of the Confucian-heritage learning culture. In D. Watkins, \& J. Biggs (Eds.), The Chinese Learner: Cultural, Psychological and Contextual Influences (p.45-68). Hong Kong: Comparative Education Research Centre and Australian Council for Educational Research.

Biggs, J. (1998). Learning from the Confucian heritage: so size doesn't matter? International Journal of Educational Research, 29, 687-688.

Blatchford, P. (2003). The Class Size Debate: is small better? Philadelphia: Open University Press.

Blatchford, P., Kutnick, P., Baines, E., \& Galton, M. (2003). Toward a social pedagogy of classroom group work. International Journal of Educational Research, 39 153172.

Blatchford, P., Bassett, P, and Brown, P. (2011). Examining the effect of class size on classroom engagement and teacher-pupil interaction: Differences in relation to pupil prior attainment and primary vs. secondary schools, Learning and Instruction, 21(6), 715-730. 
Blatchford, P. (2011). The Three Generations of Research on Class Size Effects. In Harris, K.R., Graham, S, \& Urdan, T. (2011). The American Psychological Association Educational Psychological Handbook.

Brophy, J \& Good, T.L. (1986). Teacher Behaviour and student achievement in Wittrock, M. (Ed.) Handbook of Research Teaching, $3^{\text {rd }}$ edition, New York, NY: Macmillan.

Bourke, S. (1986). How smaller is better: some relationships between class size, teaching practices, and student achievement. American Educational Research Journal, 23 (4), 558-571.

Brophy, J. (1992). Probing the Subtleties of Subject-Matter Teaching. Educational Leadership, 49 (7) 4-8.

Cahen, L. S., Filby, N., McClutcheon, G., and Kyle, D.W. (1983). Class Size and Instruction. White Plains, NY: Longman.

Ellis, R. (1998). Research and Language Teaching. Oxford: Oxford University Press

Finn, J. D., and Achilles, C.M. (1999). Tennessee's Class Size Study: Findings, Implications, Misconceptions. Educational Evaluation and Policy Analysis, 21(2), 97-111.

Galton, M., and Patrick, H. (1990). Curriculum provision in the small primary school. London: Routledge.

Galton, M. (1998). Class Size: a critical comment on the research. International Journal of Educational Research, 29, 809-818.

Galton, M., and Pell. T. (2010) Study on Small Class Teaching in Primary Schools in Hong Kong. Hong Kong: Education Bureau and Cambridge University.

Goldstein, H., and Blatchford, P. (1998). Class size and educational achievement: a review of methodology with particular reference to study design. British Educational Research Journal, 24 (3), 255-268.

Graue, E., and Rauscher, E. (2009), Researcher perspectives on class size reduction, Education Policy Analysis Archives, 17 (9), 1-22.

Hargreaves, L., Galton, M. \& Pell, A. (1998). The effects of changes in class size on teacher-pupil interactions. International Journal of Educational Research, 29, (pp.779-795).

Jin, L., and Cortazzi, M. (1998). A Dialogue: large classes in China. International Journal of Educational Research, 29, 739-761. 
Johnston, J. (1989). Teacher perceptions of changes in teaching when they have a small class or an aide. Peabody Journal of Education, 67 (1), 106-122

Johnson, K.E. (2009). Second Language Teacher Education: A Sociocultural Perspective, New York: Routledge.

Lincoln, Y. and Guba, E. (1985). Naturalistic Inquiry. Newbury Park, CA: Sage.

Littlewood, W. (1999). Defining and developing autonomy in East Asian contexts. Applied Linguistics, 20, (1), 71-94.

Lortie, D. (1975). Schoolteacher: A sociological study. Chicago: University of Chicago Press.

Miles, M. and Huberman, M.A. (1994). Qualitative Data Analysis (second edition). Beverly Hills: Sage Publications.

Molnar, A., Smith, P., and Zahorik, J. (1999). 1998-1999 evaluation of results of the Student Achievement Guarantee in Education (SAGE) program. Milwaukee: University of Wisconsin, School of Education.

Pedder, D. (2001). The impact of class size on effective teaching and learning: a conceptual and methodological investigation. Unpublished $\mathrm{PhD}$ dissertation, University of Cambridge, Faculty of Education.

Pedder, D. (2006). Are small classes better? Understanding relationships between class size, classroom processes and pupils' learning. Oxford Review of Education, 32 (2), 213-234.

Rice, J. K. (1999). The impact of class size on instructional strategies and the use of time in high school mathematics and science courses. Educational Evaluation and Policy Analysis, 21 (2), 215-229.

Shapson, S. M., Wright, E.N., Eason, G., and J. Fitzgerald. (1980). An experimental study of the effects of class size. American Educational Research Journal, 17, 141-152.

Sinclair, J. and Coulthard, M. (1975). Towards an Analysis of Discourse. Oxford: Oxford University Press.

Stake, R. (1995). The Art of Case Study Research. Thousand Oaks, CA: Sage.

Stasz, C., \& Stecher, B.M. (2002). Before and after class size reduction. In J.D. Finn \& M.C. Wang (Eds.), Taking small classes one step further (pp.19-50). Greenwich, CT: Information Age. 
Strauss, A., \& Corbin, J. (1998). Basics of qualitative research: Grounded theory procedures and techniques. Newbury Park, CA: Sage.

Tsui, A. B.M. (2003). Understanding Expertise in Teaching. Cambridge: Cambridge University Press.

Tuckman, B.W., (1972). Conducting Educational Research. New York: Harcourt Brace Jovanovich.

Wang, M.C. \& Finn, J.D. (2000). (Eds.), How Small Classes Help Teachers Do Their Best. Philadelphia, Pa.: Temple University Center for Research in Education.

Walsh, S. (2006). Investigating Classroom Discourse. Oxon, UK: Routledge.

Wilson, V. (2002). Does small really make a difference? A review of the literature on the effects of class size on teaching practice and pupils' behaviour and attainment. Scottish Council for Research in Education (SCRE) Centre: University of Glasgow.

Yin, R. (1991). Applications of case study research. Washington, DC: Cosmos Corp. 